\title{
Effective callus induction and plant regeneration in callus and protoplast cultures of Nigella damascena $\mathrm{L}$.
}

\author{
Magdalena Klimek-Chodacka $^{1}\left(\mathbb{D} \cdot\right.$ Dariusz Kadluczka $^{1}$ (D) Aneta Lukasiewicz ${ }^{1}$ (D) Aneta Malec-Pala ${ }^{1}$. \\ Rafal Baranski ${ }^{1}$ (D) Ewa Grzebelus ${ }^{1}$ (i)
}

Received: 22 May 2020 / Accepted: 15 October 2020 / Published online: 21 October 2020

(C) The Author(s) 2020

\begin{abstract}
In this study we report the development of effective in vitro systems for a medicinal plant Nigella damascena L. comprising: (1) callus induction, (2) somatic embryogenesis in callus cultures with subsequent plant regeneration, and (3) isolation and regeneration of callus-derived protoplasts. Callus development was achieved on 83-100\% of hypocotyl and cotyledon explants, whereby Murashige and Skoog medium (MS) supplemented with $3 \mathrm{mg} \mathrm{L}^{-1}$ 6-benzylaminopurine and $0.5 \mathrm{mg} \mathrm{L}^{-1}$ $\alpha$-naphthaleneacetic acid (NAA; BN medium) was more advantageous than MS with kinetin and NAA (KN medium). Histological observations of calli revealed the presence of embryogenic zones from which somatic embryos developed on the hormone-free medium. Plant regeneration was observed on 76-95\% of calli. A high capacity to form somatic embryos and regeneration was maintained in long-lasting cultures, i.e. even in 2 year old callus.

The obtained callus was also a good source tissue for protoplast isolation. By applying a mixture of cellulase and pectolyase, the acceptable yield of viable protoplasts was achieved, especially from hypocotyl-derived callus maintained on BN medium. Protoplasts embedded in an alginate matrix and cultured in modified Kao and Michayluk media re-constructed their cell wall and re-entered mitotic divisions. About $30 \%$ of small cell aggregates formed microcalli, which, after the release from alginate, proliferated continuously on $\mathrm{KN}$ and $\mathrm{BN}$ media, irrespective of the tissue variant used as the protoplast source. Somatic embryo formation and plant regeneration were successful on hormone-free media. An effective plant regeneration system of $N$. damascena protoplast cultures has been developed and is being reported for the first time.
\end{abstract}

\section{Key message}

The main objective of this study was to develop in vitro systems utilizing $N$. damascena seedlings, asan easily accessible explant source, for efficient callus induction and proliferation, and plantregeneration via somatic embryogenesis. Moreover, we attempted to validate the usefulness of theobtained callus as a source of protoplasts and their capability to develop into plants.

Keywords Cotyledon $\cdot$ Hypocotyl $\cdot$ Somatic embryogenesis $\cdot$ Love-in-a-mist $\cdot$ Medicinal plant $\cdot$ Ranunculaceae

Communicated by Danny Geelen.

Electronic supplementary material The online version of this article (https://doi.org/10.1007/s11240-020-01953-9) contains supplementary material, which is available to authorized users.

Magdalena Klimek-Chodacka

m.chodacka@urk.edu.pl

Ewa Grzebelus

ewa.grzebelus@urk.edu.pl

1 Department of Plant Biology and Biotechnology, Faculty of Biotechnology and Horticulture, University of Agriculture in Krakow, al. 29 Listopada 54, 31-425 Krakow, Poland

\author{
Abbreviations \\ BAP 6-Benzylaminopurine \\ CPP Carrot petiole protoplast medium \\ 2,4-D 2,4-Dichlorophenoxyacetic acid \\ FDA Fluorescein diacetate \\ FW Fresh weight \\ NAA $\alpha$-Naphthaleneacetic acid \\ PSK Phytosulfokine- $\alpha$ \\ $\mathrm{Pu} \quad$ Putrescine
}




\section{Introduction}

The genus Nigella L. (Ranunculaceae) includes about 20 species (Boubertakh et al. 2013) that are mostly considered weeds, but also used as ornamentals and species valuable in traditional medicine, e.g. N. sativa, $N$. damascena, $N$. arvensis (Kökdil and Yilmaz 2005). Certain health properties of Nigella species have been proven experimentally and adapted for treatments in modern medicine. N. sativa, commonly known as black cumin, is the most studied species of this genus and has been used to treat cardiovascular diseases, diabetes (Charles 2013), and neurodegenerative diseases (Noor et al. 2015), and anti-cancerogenic properties have also been reported (Khan et al. 2011). It has also been shown that $N$. sativa exhibits anti-cancer activity due to the presence of thymoquinone, the main component of its essential oil. Another sesquiterpene, $\beta$-elemene, also has great therapeutic potential, which, in turn, undergoes intensive biosynthesis in $N$. damascena, an annual herbaceous plant (D'Antuono et al. 2002; Edris et al. 2009). $N$. damascena, commonly known as love-in-a-mist or devil-in-the-bush, is native to the Mediterranean region and West Asia, but today is grown as an ornamental plant in temperate regions of Europe (Fico et al. 2000; Jabbour et al. 2015). The entomophilous flowers consist of usually blue petaloid sepals lying on lacy bracts and long-stalked petals located at the base of the stamens (Zhao et al. 2011; Liao et al. 2020). The seeds of N. damascena are produced in bloated capsules that partially open on the dorsal and ventral suture (Zohary 1983). They contain fatty acids (linoleic, oleic, palmitic) (Telci et al. 2014), proteins (e.g. albumin, glutein, globulin), and other biologically active compounds, such as $\beta$-elemene and its precursor, germacrene A (de Kraker et al. 1998), which is valued for antimicrobial activity, and damascenine, an alkaloid known for antipyretic, analgesic, and anti-edematous properties. In addition to the medicinal value, seeds of $N$. damascena are also used as a food preservative and spice, due to their strawberry-like scent that is determined by capronic and butyric esters (Wajs et al. 2009).

Presently, plants are widely used in industry for the production of different kinds of primary and secondary metabolites, which are used as dyes, fragrances, food additives, insecticides, or drugs (Hussain et al. 2012). Plant cell and tissue culture systems in bioreactors are commonly used in the production of such active compounds (Ebrahimi and Mokhtari 2017). However, to be able to synthesize secondary metabolites in tissue cultures, appropriate techniques need to be developed and work efficiently. Not only is it necessary to effectively induce and proliferate callus tissue/suspension cultures, but also to efficiently induce the synthesis of metabolites (Mulabagal et al. 2004). It is known that if culture conditions are well optimized, the in vitro culture systems may offer much more efficient production than field grown plants (Mulabagal and HsinSheng 2004). In the biosynthesis of industrially exploited metabolites, protoplast-based systems may also be useful, as they give the opportunity to increase biodiversity through cell fusion between closely and distantly related species. In that way it is possible to develop materials that are unique from a medical point of view, with increased content or a new set of biologically active substances. In addition, the ability of in vitro-derived tissues for plant regeneration is a relatively important factor during other in vitro-based techniques, such as genetic transformation or CRISPR-based genome editing, which may serve as an alternative way to generate new biodiversity. Thus far, a limited number of protocols have been presented for $N$. damascena and only for selected in vitro techniques. Raman and Grayson (1974) described an efficient protocol for somatic embryo production in suspension cultures but the applied procedure was time consuming and laborious, as it was preceded by callus induction from floral meristems and suspension culture initiation. In the second existing report, callus was induced on the endosperm tissue of mature seeds, however subsequent development of somatic embryos was arrested at the globular stage, probably due to triploid status of the cells (Sethi and Rangaswamy 1976). More data concerning callus induction, suspension culture initiation, and plant regeneration are available for the closely related $N$. sativa (for review, see Kazmi et al. 2019). It remains unrevealed whether there is any analogy between $N$. sativa and $N$. damascena in response to cell and tissue culture in vitro. It has been commonly reported that procedures developed for one species can seldom be applied to its relatives, even of the same genus, and they should be carefully refined at the species, subspecies, cultivar, or even donor tissue level (Eeckhaut et al. 2013; Shahzad et al. 2017; Bridgen et al. 2018; Grzebelus et al. 2019).

In light of the potential value of $N$. damascena cell or tissue cultures for biotechnological applications, the main objective of this study was to develop in vitro systems utilizing $N$. damascena seedlings, as an easily accessible explant source, for efficient callus induction and proliferation, and plant regeneration via somatic embryogenesis. Moreover, we attempted to validate the usefulness of the obtained callus as a source of protoplasts and their capability to develop into plants. 


\section{Materials and methods}

\section{Donor plant material}

Seeds of Nigella damascena L. (provided by Polan-Polish seed company) were surface-sterilized by sequential soaking in $70 \%$ ethanol for $10 \mathrm{~min}$ and $30 \%$ (v/v) sodium hypochlorite for $20 \mathrm{~min}$, followed by three washes in sterile distilled water. After drying on a sterile paper, the seeds were placed in plastic jars on solid germination medium containing Murashige and Skoog mineral salts and vitamins (Murashige and Skoog 1962; MS medium; Duchefa Biochemie, The Netherlands), supplemented with $30 \mathrm{~g} \mathrm{~L}^{-1}$ sucrose $(\mathrm{POCH}$, Poland) and $0.7 \%(\mathrm{w} / \mathrm{v})$ agar (Biocorp, Poland). Seeds were then incubated in a phytotron at $26 \pm$ $2{ }^{\circ} \mathrm{C}$ with a $16 / 8 \mathrm{~h}$ (light/dark) photoperiod (a light intensity of $80 \mu \mathrm{mol} \mathrm{m}{ }^{-2} \mathrm{~s}^{-1}$ ) for 3 weeks.

\section{Callus induction and plant regeneration from callus tissue}

Hypocotyl and cotyledon fragments, approximately 1 $\mathrm{cm}$ in length, were excised from donor seedlings and used as explants for callus induction. Callus induction was performed on two MS mineral media with vitamins (Murashige and Skoog 1962) supplemented with $30 \mathrm{~g}$ $\mathrm{L}^{-1}$ sucrose and different compositions of growth regulators, i.e. $2 \mathrm{mg} \mathrm{L}^{-1}$ kinetin (Duchefa) and $1 \mathrm{mg} \mathrm{L}^{-1}$ $\alpha$-naphthaleneacetic acid (NAA; Duchefa) [KN medium] or $3 \mathrm{mg} \mathrm{L}^{-1}$ 6-benzylaminopurine (BAP; Duchefa) with $0.5 \mathrm{mg} \mathrm{L}^{-1}$ NAA [BN medium]. Both media were adjusted to $\mathrm{pH} 5.8$ and solidified with $0.7 \%$ (w/v) agar (Biocorp). Cultures were kept at $26{ }^{\circ} \mathrm{C}$ in the dark. Explants were subcultured onto the same fresh media every 3 weeks. Each experimental variant (explant/medium combination) was set up in three replications and each replication was represented by 12-16 hypocotyl or 27-32 cotyledon explants. After 6 weeks of culture, the callus formation rate, expressed as a percentage of explants forming callus, was evaluated for each variant. Obtained callus clumps were transferred onto the hormone-free plant regeneration medium containing MS salts and vitamins, supplemented with an additional $1 \mathrm{mg} \mathrm{L}^{-1}$ glycine (Duchefa), $20 \mathrm{~g} \mathrm{~L}^{-1}$ sucrose, adjusted to $\mathrm{pH} 5.8$, solidified with $0.2 \%(\mathrm{w} / \mathrm{v})$ phytagel (Sigma-Aldrich, Germany), and incubated under the same conditions as donor seedlings. Each regeneration variant was set up in five replications and each replication consisted of five hypocotyl/cotyledon-derived callus clumps. 3 week old cultures were subcultured once on a fresh medium. The evaluation of the experiment was done after 6 weeks of culture by determining the number of regenerating callus clumps and the number of regenerated plants per callus clump.

Hypocotyl- and cotyledon-derived callus tissues were maintained for at least 2 years under in vitro conditions with regular subcultures every 3 weeks on fresh $\mathrm{KN}$ or $\mathrm{BN}$ media. After 2 years, their regeneration potential was examined again by transferring long-term callus tissues onto the regeneration medium and plant regeneration was performed as described above.

\section{Histological observations of callus tissue during regeneration}

For histological examination, samples of tissue clumps collected from the solid medium 4 weeks after induction of regeneration, were fixed in freshly prepared $100 \mathrm{mM}$ phosphate buffer $(\mathrm{pH} 7.2)$ containing $2 \%(\mathrm{v} / \mathrm{v})$ formaldehyde $(\mathrm{POCH})$ and $3 \%(\mathrm{v} / \mathrm{v})$ glutaraldehyde $(\mathrm{POCH})$ for at least 48 $\mathrm{h}$ at room temperature (with vacuum infiltration within the first $10 \mathrm{~min}$ ). After fixation, the tissue samples were dehydrated in a graded ethanol series $(10 \%, 30 \%, 50 \%, 70 \%$, and $90 \%$ for 15 min each) and left overnight in absolute ethanol. The dehydrated material was embedded in Technovit ${ }^{\circledR}$ 7100 resin (Kulzer, Germany), according to the manufacturer's protocol. When polymerized, the samples were sectioned into slices of $4 \mu \mathrm{m}$ thickness using a Leica RM2145 rotary microtome (Leica Microsystems GmbH, Germany) with a Leica TC-65 carbide blade. The sections were then stained with $1 \%$ (w/v) toluidine blue O (Sigma-Aldrich), permanently mounted in Entellan ${ }^{\circledR}$ (Merck, Germany), and examined under an Axio Imager.M2 microscope (Carl Zeiss, Germany).

\section{Isolation and culture of callus-derived protoplasts}

As a source material, long-term (i.e. 5-14 months old) cultures of hypocotyl- and cotyledon-derived callus tissues maintained on $\mathrm{KN}$ and $\mathrm{BN}$ media were used. For each experiment, protoplasts were isolated from callus tissue grown for 2 weeks on fresh medium (Fig. 3a), following the procedure described by Grzebelus and Skop (2014). Briefly, before enzyme maceration, callus clumps were chopped into small pieces in a preplasmolysis solution $(0.5 \mathrm{M}$ mannitol) and incubated for $1 \mathrm{~h}$ at room temperature. Release of protoplasts took place overnight in a one-step protocol by the simultaneous digestion of callus tissue in a mixture of $1 \%(\mathrm{w} / \mathrm{v})$ cellulase (Duchefa) and $0.1 \%(\mathrm{w} / \mathrm{v})$ pectolyase (Duchefa). For protoplast purification, the cell suspension was separated from an undigested tissue matrix by filtration through a nylon sieve following density gradient centrifugation. Before culturing in the protoplast medium, cells were embedded in a filter-sterilized sodium alginate solution and thin alginate layers were formed according to a previously 
established protocol (Maćkowska et al. 2014). The final plating density of protoplasts embedded in an alginate matrix was adjusted to $4 \times 10^{5}$ cells per $\mathrm{ml}$. The alginate layers with immobilized protoplasts were then transferred into $4 \mathrm{ml}$ of the liquid culture medium in 6-cm Petri dishes. The protoplast culture medium was based on the CPP medium (Dirks et al. 1996) and consisted of macro- and microelements and organic acids, according to Kao and Mychayluk (1975); vitamins, according to B5 medium (Gamborg et al. 1968); $74 \mathrm{~g}$ $\mathrm{L}^{-1}$ glucose (POCH); $250 \mathrm{mg} \mathrm{L}^{-1}$ casein enzymatic hydrolysate (Sigma-Aldrich) and growth hormones, as in callus induction medium, i.e. $2 \mathrm{mg} \mathrm{L}^{-1}$ kinetin and $1 \mathrm{mg} \mathrm{L}^{-1} \mathrm{NAA}$ (CPP1 medium) or $3 \mathrm{mg} \mathrm{L}^{-1} \mathrm{BAP}$ and $0.5 \mathrm{mg} \mathrm{L}^{-1} \mathrm{NAA}$ (CPP2 medium). Both media were adjusted to $\mathrm{pH} 5.6$ and filter-sterilized. Additionally, CPP1 and CPP2 media were supplemented with 10,100 , or $1000 \mathrm{nM}$ phytosulfokine- $\alpha$ (PSK; PeptaNova GmbH, Germany; experiment no. 1), 50 or $100 \mu \mathrm{M}$ putrescine (Pu; Sigma-Aldrich), and $50 \mu \mathrm{M} \mathrm{Pu}$ and $100 \mathrm{nM}$ PSK (experiment no. 2). For protoplasts isolated from callus tissues that were maintained on $\mathrm{KN}$ and $\mathrm{BN}$ media, CPP1 and CPP2, respectively, were used as basal protoplast culture media. Protoplast cultures were incubated at $26 \pm 2{ }^{\circ} \mathrm{C}$ in the dark. After 10 days of culture, the medium with all supplements was replaced by a fresh one for each culture variant.

\section{Plant regeneration from protoplast-derived tissue}

After about three months of protoplast culture, protoplastderived tissues were released from the alginate matrix by incubation of the alginate layers in a $20-\mathrm{mM}$ sodium citrate solution, as described by Grzebelus et al. (2012a). Following alginate solubilization, the alginate residues and citrate solution were removed from the CPP1- and CPP2-based cultures by centrifugation (twice at $100 \times g$ for $5 \mathrm{~min}$ ) in CPP1 and CPP2 media, respectively. Finally, $1 \mathrm{ml}$ aliquots of purified mass tissues were plated on a filter-paper disk placed directly in Petri dishes $(90 \times 25 \mathrm{~mm})$ on the $\mathrm{KN}$ and $\mathrm{BN}$ medium, respectively. The cultures were maintained at $26 \pm 2{ }^{\circ} \mathrm{C}$ in the dark. Every 3 weeks, newly produced tissue was subcultured on the same fresh media. For plant regeneration, callus clumps were transferred onto the hormone-free medium and incubated in a phytotron at $26 \pm 2{ }^{\circ} \mathrm{C}$ with a $16 / 8 \mathrm{~h}$ (light/ dark) photoperiod (a light intensity of $80 \mu \mathrm{mol} \mathrm{m}^{-2} \mathrm{~s}^{-1}$ ), with a 3-week interval subculture.

\section{Data collection and analysis}

\section{Callus induction and plant regeneration}

In experiments concerning callus induction and plant regeneration from hypocotyl- or cotyledon-derived callus, means and the standard error of the means were calculated. Data were subjected to two-way analysis of variance (ANOVA) using Statistica ver. 12 (StatSoft, Inc. 2014). Tukey's posthoc test was used to determine significant differences between the means.

\section{Protoplast cultures}

Protoplast yield, expressed as the number of protoplasts per gram of fresh weight (FW) of callus tissue, was determined using the Fuchs-Rosenthal counting chamber. The viability of embedded protoplasts was assessed by staining the cultured cells just after immobilization with fluorescein diacetate (FDA), according to Anthony et al. (1999), and presented in percentages. Plating efficiency was determined in 10 day old cultures and expressed as the number of cell aggregates per total number of observed undivided cells and cell aggregates $(\times 100)$. Microscopic observations of protoplast cultures were performed under an Axiovert S100 microscope (Carl Zeiss) equipped with a filter set appropriate for FDA detecting $\left(\lambda_{\mathrm{Ex}}=485 \mathrm{~nm}, \lambda_{\mathrm{Em}}=515 \mathrm{~nm}\right)$.

For replications, at least five to nine independent protoplast isolation experiments with a single treatment represented by three Petri dishes were carried out. Microscopic observations were performed on 100-200 cells per Petri dish. The overall effect of treatments was determined using ANOVA in Statistica and Tukey's honestly significant difference test was used for mean separation.

Before releasing protoplast-derived tissue from the alginate matrix, the level of culture development was determined according to a two-step descriptive scale and expressed as poor growth of callus tissue if alginate layers were not overgrown with callus $(+)$ or good growth of callus tissue if alginate layers were overgrown with callus $(+++)$. Similarly, a descriptive scale was used in case of plant regeneration; for each culture variant, only events of proembryonic mass and somatic embryos formation, as well as plant development, were noted.

\section{Results}

\section{Callus induction}

Nigella damascena seeds germinated with a relatively low efficiency $(<15 \%$, data not shown) and despite rigorous seed-surface sterilization, fungal contamination was still encountered. Nevertheless, after 3 weeks of culture initiation, well-developed seedlings were obtained. Hypocotyland cotyledon-derived explants were cultured in the dark on two different media. Callus appeared on both explant types in the first 3 weeks of culture and its growth was fast. However, callus formation of the hypocotyl-derived explants was more effective compared to the cotyledon-derived ones, 
Table 1 Callus induction efficiency depending on media composition and type of explants

\begin{tabular}{lllll}
\hline $\begin{array}{l}\text { Callus } \\
\text { induction } \\
\text { medium }\end{array}$ & Explant type & $\begin{array}{l}\text { Total number of } \\
\text { explants }\end{array}$ & $\begin{array}{l}\text { Callus formation } \\
\text { rate } \\
\text { SE }(\%) \text { Mean } \pm\end{array}$ \\
\cline { 3 - 5 } & & Cultured $\begin{array}{l}\text { Induc- } \\
\text { ing } \\
\text { callus }\end{array}$ \\
\hline KN & Hypocotyl & 48 & 40 & $83 \pm 9.6^{\mathrm{b}}$ \\
& Cotyledon & 96 & 95 & $99 \pm 1.3^{\mathrm{a}}$ \\
BN & Hypocotyl & 40 & 40 & $100 \pm 0^{\mathrm{a}}$ \\
& Cotyledon & 83 & 83 & $100 \pm 0^{\mathrm{a}}$ \\
\hline
\end{tabular}

${ }^{\mathrm{a}}$ Number of explants forming callus/total number of cultured explants $\times 100$

$\mathrm{KN}=\mathrm{MS}$ medium $+2.0 \mathrm{mg} \mathrm{L}^{-1}$ kinetin $+1.0 \mathrm{mg} \mathrm{L}^{-1} \mathrm{NAA} ; \mathrm{BN}=$ $\mathrm{MS}$ medium + $3.0 \mathrm{mg} \mathrm{L}^{-1} \mathrm{BAP}+0.5 \mathrm{mg} \mathrm{L}^{-1} \mathrm{NAA}$

Means followed by the same letter were not significantly different at $P=0.05$

covering $50 \%$ of the explants' surface. During further culture, the callus tissue covered the whole explant and proliferated efficiently (Online Resource 1). Regardless of the medium used, the hypocotyl-derived callus was intensely yellow, while the cotyledon-derived callus was almost white and matte. No symptoms of tissue darkening or dying were observed.

Callus induction in all tested combinations of explants and media were effective (Table 1). In general, callus was more frequently formed on cotyledons than on hypocotyls $(P=0.02)$, and on $\mathrm{BN}$ medium than on $\mathrm{KN}$ medium $(P=$ 0.01 ). Using BN medium containing BAP and NAA, callus was obtained on all explants, regardless of the explant type. A similarly high efficiency of callus induction was observed when cotyledons were cultured on $\mathrm{KN}$ medium containing kinetin and NAA. Only the incubation of hypocotyls on the $\mathrm{KN}$ medium gave a lower percentage of callus formation $(83 \%)$.

\section{Plant regeneration from callus tissue}

6 week old calli were transferred to hormone-free regeneration medium and after 2 weeks of culture, shoot development was observed on almost every callus clump (Fig. 1). The pattern of morphogenesis indicated their origin from somatic embryos. Plant regeneration occurred on over 95\% of hypocotyl-derived calli, regardless of the medium used at the callus induction stage. In general, the regeneration efficiency was independent of the medium used for callus induction $(P=0.18)$, while the explant type had a significant impact $(P<0.01)$. The efficiency of plant formation from cotyledon-derived callus proliferated on $\mathrm{BN}$ medium was comparable to the regeneration from hypocotyl-derived callus, while significantly lower efficiency was noted when the KN medium was used (76\%).

The number of regenerated shoots depended on both the explant type and medium composition $(P<0.05)$. The largest number of regenerated plants was obtained from hypocotyl-derived callus proliferated on KN medium, which was on average six plants per one callus clump. For other explant and media combinations, the number of regenerated plants was almost halved. In vitro produced plants were characterized by well-developed leaves and roots with root hairs and showed no morphological abnormalities.

Long-term cultures had no visible adverse effects on callus cultures. After 2 years of culture, efficient somatic embryo formation and plant production was achieved from all experimental variants when callus was transferred onto the regeneration medium (Fig. 1c). Conversion of somatic embryos into plants occurred 2 weeks after callus culture on hormone-free medium and the efficiency of plant development was at a similar level as the efficiency obtained from a short-term callus culture (data not shown).

\section{Histological observations of regeneration from callus tissue}

Microscopic observations of callus histological sections revealed distinguishable embryogenic and non-embryogenic zones (Fig. 2a). In contrast to the large, vacuolated cells of the non-embryogenic tissue that was loosely arranged with wide intercellular spaces, the embryogenic clusters were composed of small-sized, compact cells of isodiametric shape, with large, dark blue-stained nuclei and prominent nucleoli, indicating their meristematic nature. Such multicellular meristematic masses gave rise to somatic embryos, of which various developmental stages were observed (Fig. 2a-e). The formation of somatic proembryos with the presence of a suspensor-like structure was also detected (Fig. 2a). From the embryogenic clumps, globular-shaped embryos formed, surrounded by a differentiating embryonic epidermis (protoderm) (Fig. 2b) and further developed into heart-shaped embryos, in which the protoderm was more distinct and the cotyledons were clearly shaped (Fig. 2c-d). In some cases, the embryos were attached to the callus tissue by multicellular suspensor-like structures, however, they were not always observed. In mature embryos, the basal domain, comprising the hypocotyl, radicle, and primary root meristem, was fully developed (Fig. 2e), with intensive cell divisions in the meristematic region (Fig. 2e, arrows). Occasionally, areas of vascular tissues were scattered within the nonembryogenic mass (Fig. 2f). 


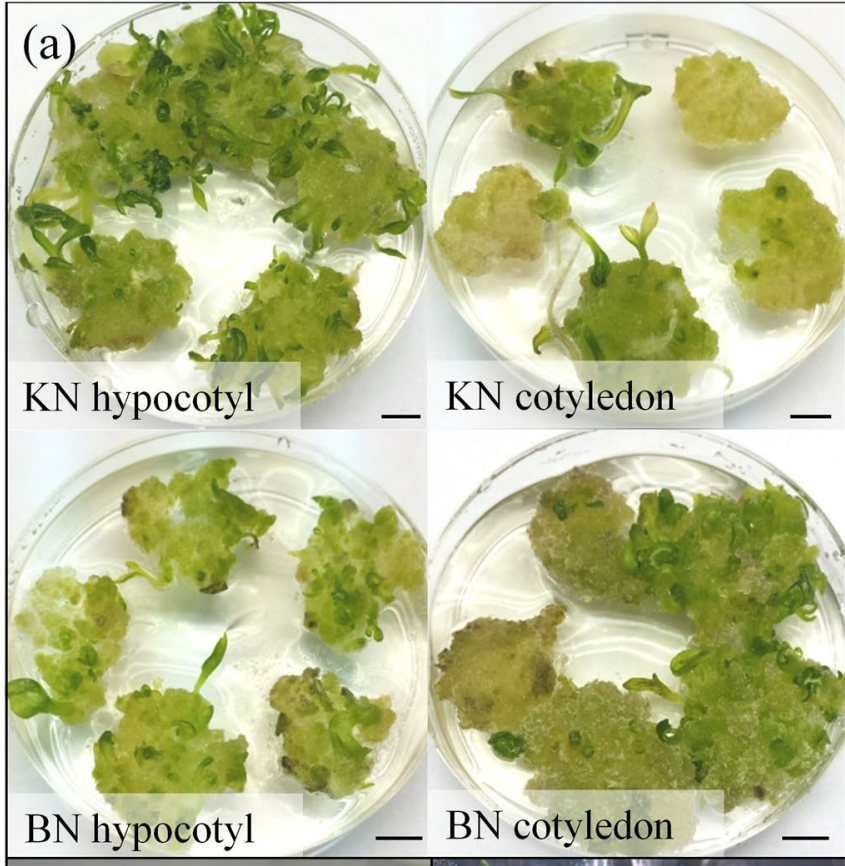

(d)

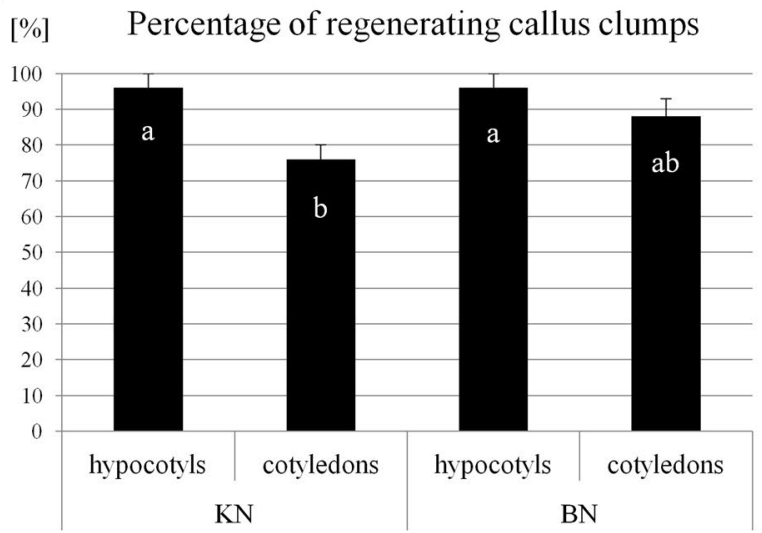

Average, minimum and maximum number of No. $\quad$ regenerated plants per callus clump
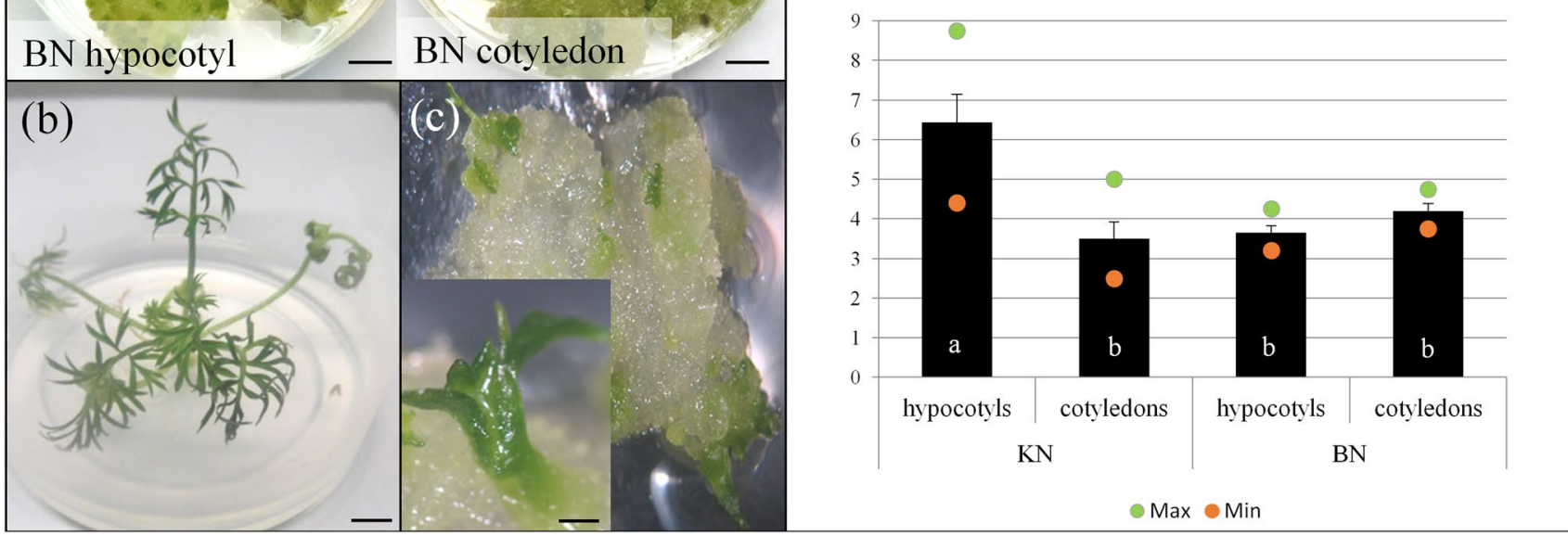

Fig. 1 Efficiency of plant regeneration from callus tissue of Nigella damascena. a Plant regeneration from hypocotyl- and cotyledonderived callus (induced on $\mathrm{KN}$ or BN medium) after 6 weeks of culture on hormone-free medium; $\mathbf{b}$ regenerated plant; $\mathbf{c}$ regeneration on 2 year old callus; $\mathbf{d}$ regeneration efficiency expressed as the percentage of regenerating callus clumps and the average number of regen-

\section{Yield and viability of callus-derived protoplasts}

After overnight incubation of hypocotyl- and cotyledonderived callus tissue in a cell wall-digesting enzyme mixture, spherical protoplasts of different sizes were released (Fig. 3b). Most of them were bright with a densely organized cytoplasm, while some were yellow, probably due to the presence of carotenoids or sterols. The efficiency of protoplast isolation reached, on average, about $3 \times 10^{5}$ cells per $\mathrm{g}$ of callus fresh weight (Table 2). The most efficient protoplast isolation was achieved from hypocotyl-derived callus grown on BN medium, while the use of any other protoplast source reduced the number of released protoplasts by almost half. The quality of released protoplasts was determined by using erated plants per callus clump after 6 weeks of culture on regeneration medium. $\mathrm{KN}=\mathrm{MS}$ medium $+2.0 \mathrm{mg} \mathrm{L}^{-1}$ kinetin $+1.0 \mathrm{mg} \mathrm{L}^{-1}$ $\mathrm{NAA} ; \mathrm{BN}=\mathrm{MS}$ medium $+3.0 \mathrm{mg} \mathrm{L}^{-1} \mathrm{BAP}+0.5 \mathrm{mg} \mathrm{L}^{-1} \mathrm{NAA}$. Means marked with the same letters were not significantly different at $P=0.05$. Scale bars: $0.2 \mathrm{~cm}(\mathbf{c}), 1 \mathrm{~cm}(\mathbf{a}-\mathbf{b})$

FDA staining and 49 to $65 \%$ of protoplasts emitted applegreen fluorescence (Fig. 3c); hence, they were considered viable. Cell viability reached, on average, $57 \%$ and did not vary significantly $(P=0.30)$ among source tissues.

\section{Development of protoplast cultures}

Up to the fifth day of culture, most protoplasts changed shape from spherical to oval, which was the morphological evidence of cell wall reconstruction. Other structural changes preceded the first mitotic division, such as reorganization of the cytoplasm and cell organelles (Fig. 3d). Both asymmetric and symmetric cell divisions took place (Fig. 3e-f) and in 10 day old protoplast cultures, the first 

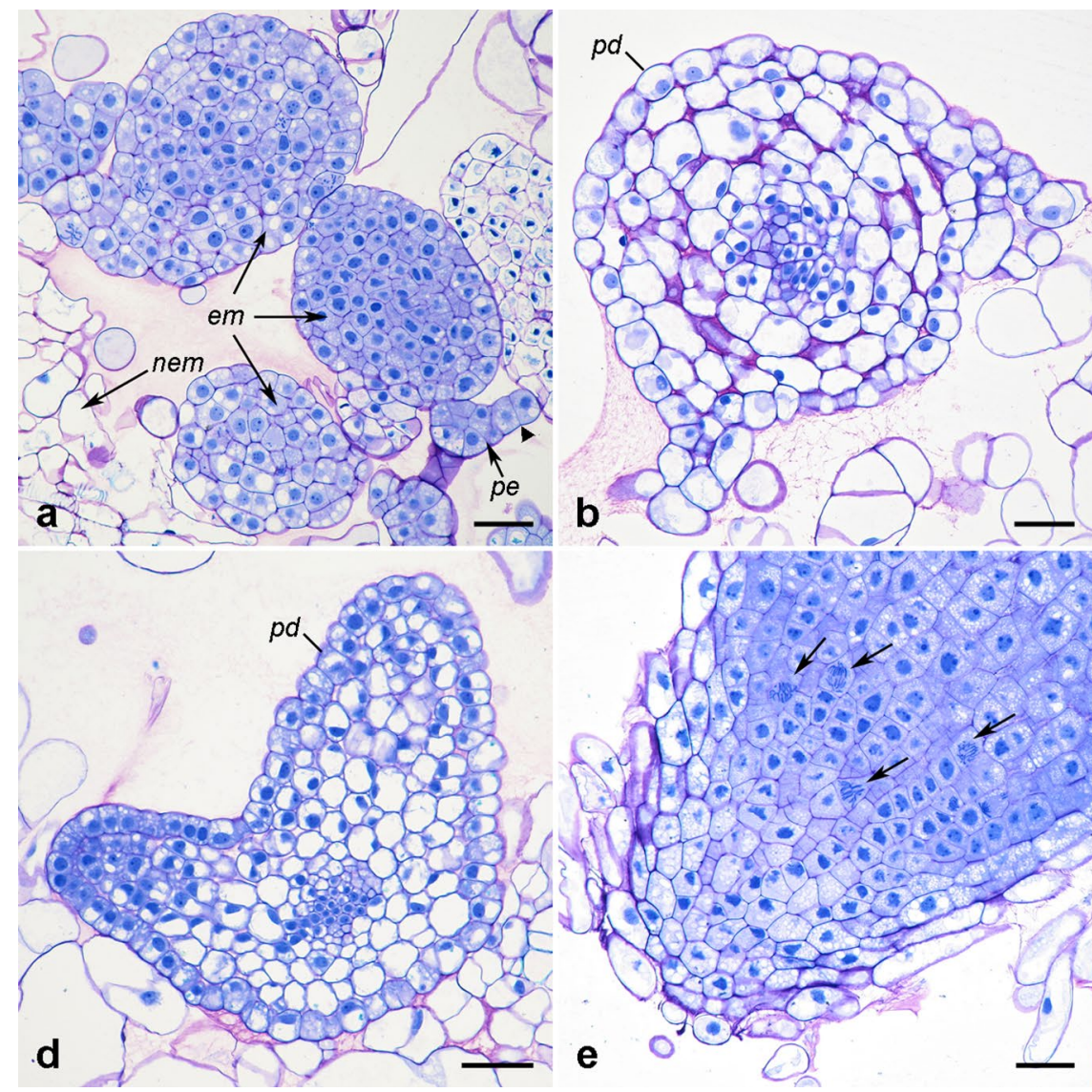

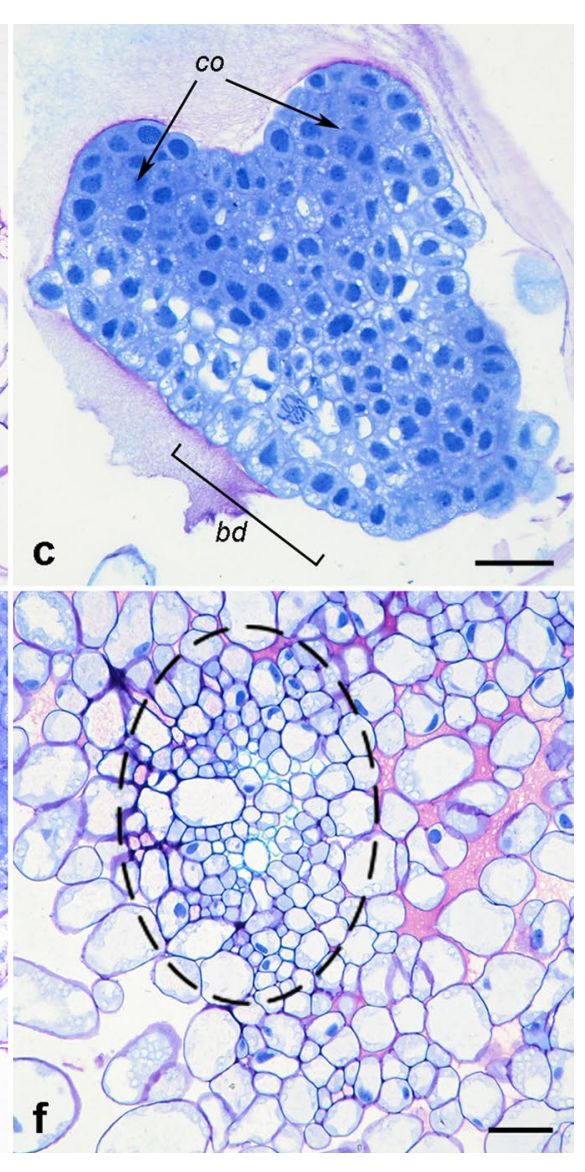

Fig. 2 Somatic embryogenesis in Nigella damascena from hypocotyl- and cotyledon-derived callus tissues. a Embryogenic (em) and non-embryogenic (nem) masses within the callus tissue (arrowhead - suspensor-like structure); b-e somatic embryos at different stages of development: b globular-shaped embryo; c early heart-shaped

multicellular aggregates (Fig. 3g) were formed. In such early cultures, the plating efficiency demonstrated by the number of cell aggregates was high and reached, on average, $88 \%$ in CPP1 and CPP2 control cultures. The number of forming cell aggregates was high and comparable in all types of culture variants. In the experiment using protoplasts originating from hypocotyl-derived callus (experiment no. 1), no effect of PSK on the plating efficiency was found, independent of the applied PSK concentration ( $P=0.96$; Fig. 4a). Similarly, no significant difference in plating efficiency was observed after media supplementation with $\mathrm{Pu}$ or $\mathrm{Pu}+\mathrm{PSK}$, independent of the protoplast source used (experiment no. 2) $(P$ $=0.92$; Fig. 4b).

Mitotic divisions were arrested over time in most cell aggregates identified in 10 day old cultures. Only approximately $30 \%$ of aggregates continued their growth that finally led to the formation of a microcallus (Fig. 3h-i).

In general, 60 day old protoplast cultures originating from hypocotyl-derived callus had poor growth of protoplast-derived callus tissue, regardless of the basal protoplast embryo; d late heart-shaped embryo; e basal domain of a mature embryo with radicle (arrows indicate dividing meristematic cells); f developing vascular tissue (dotted line) within non-embryogenic mass; $b d$ basal domain, $c o$ cotyledons, pe pro-embryo, $p d$ protoderm. Scale bar: $50 \mu \mathrm{m}$

culture medium used (CPP1 or CPP2) and PSK, $\mathrm{Pu}$, or Pu + PSK supplementation (Table 3). Only callus developed from protoplasts originating from cotyledon-derived callus proliferating on $\mathrm{KN}$ medium was characterized by vigorous growth, which was manifested by the alginate layers being overgrown with intensively growing microcalli.

\section{Plant regeneration from protoplast-derived tissue}

Protoplast-derived callus tissue released from the alginate matrix proliferated continuously on $\mathrm{KN}$ and $\mathrm{BN}$ media, irrespective of the tissue variant used as the protoplast source and conditions of protoplast culture (Fig. 3j). On average, tissue mass was doubled after each subculture. The pattern of plant regeneration was similar to that described above in the section on plant regeneration from callus. After approximately 2 weeks of culture on hormone-free medium, all variants of protoplast-derived callus tissue, proembryonic mass (Fig. 3k), and somatic embryos at different developmental stages (Fig. 31-n) were recognized. Finally, after about two 


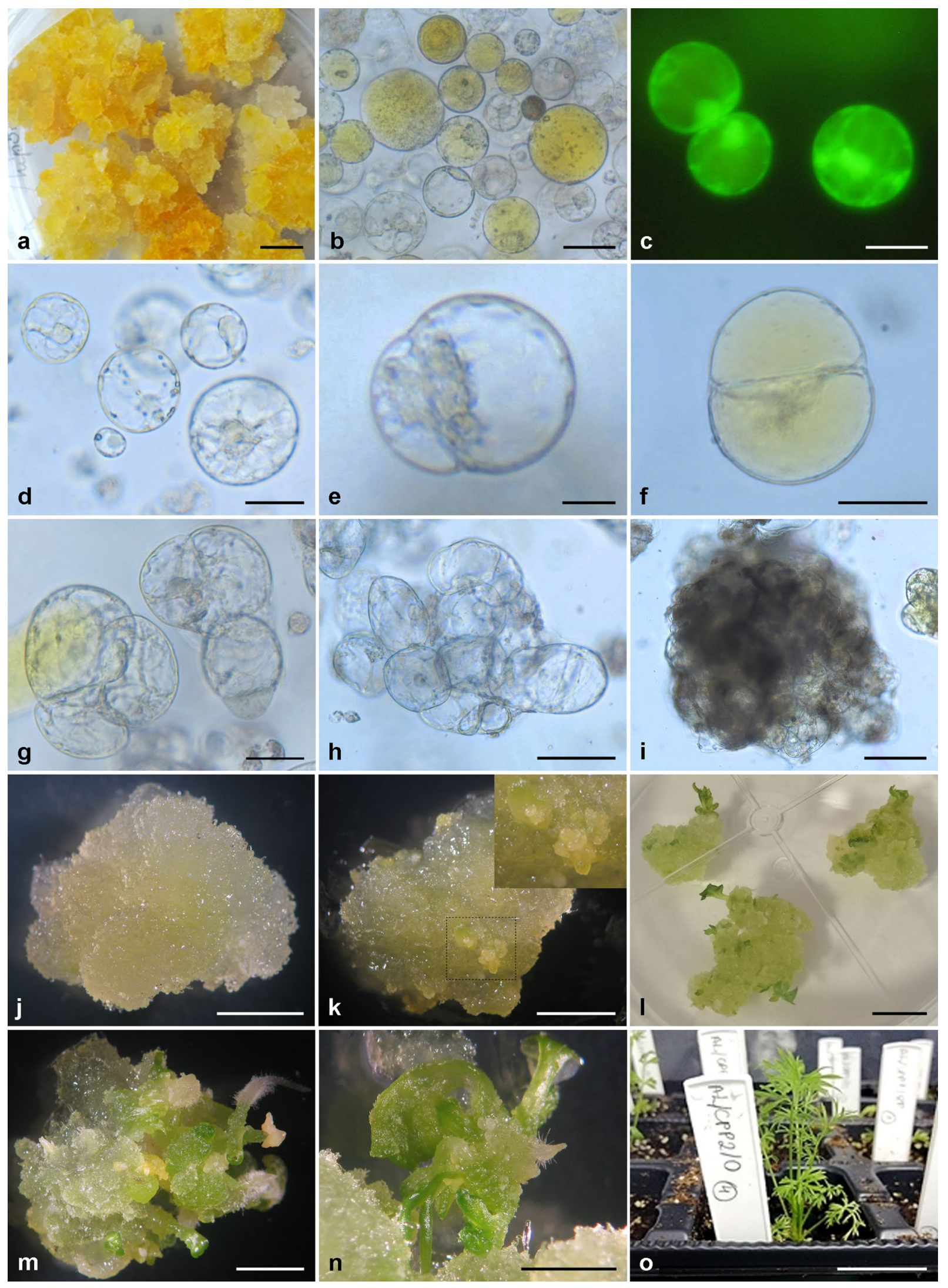


4Fig. 3 Plant regeneration from callus-derived protoplasts of Nigella damascena L. a Donor callus tissue for protoplast isolation; $\mathbf{b}$ freshly isolated protoplasts from callus tissue; $\mathbf{c}$ fluorescence of viable protoplasts stained with fluorescein diacetate; $\mathbf{d}$ reorganization of cytoplasm and localization of cell organelles in protoplasts before the first mitotic division; e asymmetric mitotic division of a protoplast; f daughter cells after the first symmetric mitotic division; multicellular aggregate in $10(\mathbf{g}), 20$ (h) and 60 day old (i) protoplast cultures; j protoplast-derived callus tissue three months after protoplast isolation; k embryogenic callus tissue (the inset shows a higher magnification of the embryogenic mass); l-n subsequent stages of plant regeneration from somatic embryos; o regenerated plants after acclimatization to ex vitro conditions. Scale bars: $20 \mu \mathrm{m}(\mathbf{e}), 50 \mu \mathrm{m}(\mathbf{b}-\mathbf{d}$, f-g), $100 \mu \mathrm{m}(\mathbf{h}), 200 \mu \mathrm{m}$ (i), $0.5 \mathrm{~cm}(\mathbf{j}-\mathbf{k}, \mathbf{m}-\mathbf{n}), 1 \mathrm{~cm}(\mathbf{a}, \mathbf{l}), 3 \mathrm{~cm}(\mathbf{o})$

months of regeneration, fully developed plants, ready for ex vitro acclimatization, were produced. Individual plants transplanted to the soil had successfully undergone the acclimatization process.

\section{Discussion}

Despite the importance of $N$. damascena as a medicinal plant, research focused on the utilization of in vitro cultures in this species is limited. Available reports mainly concern $N$. sativa, a closely related species. The effectiveness of callus induction depends on many factors, including explant source, medium composition, temperature, growth conditions, and donor plant variety, among others. The combination of cytokinins and auxins promoted callus induction in $N$. sativa (Chaudhry et al. 2014). By incubating leaf fragments and epicotyls with light on the medium containing $2 \mathrm{mg} \mathrm{L}^{-1}$ kinetin and $1 \mathrm{mg} \mathrm{L}^{-1} \mathrm{NAA}$, they obtained callus on up to $83 \%$ of explants. The combined use of $0.5 \mathrm{mg}$ $\mathrm{L}^{-1}$ BAP with $0.5 \mathrm{mg} \mathrm{L}^{-1} \mathrm{NAA}$ allowed effective induction of callus from $N$. sativa leaf explants (Hoseinpanahi et al. 2016). However, no callus was obtained when hypocotyl explants were used (Chaudhry et al. 2014). In N. damascena, floral meristems were used as explants and effective callus induction of these explants was achieved in the presence of 2,4-dichlorophenoxyacetic acid (2,4-D) and coconut milk (Raman and Grayson 1974). The use of meristems in tissue culture is troublesome and is associated with the need for long-term maintenance of plants under in vitro conditions or the introduction of plants to ex vitro conditions, which is often associated with significant contamination. In the present study, for the first time, callus was induced from defined fragments of young seedlings, i.e. cotyledon and hypocotyl explants, which can be easily obtained in large numbers and in a relatively short time. Callus tissue developed very intensively, regardless of the origin of the explants, reaching as high as $100 \%$. In our study, two combinations of cytokines and auxins were used, as was the case with N. sativa. However, the effect of the combination of plant growth regulators was insignificant, only when callus was induced on hypocotyls in the presence of kinetin and NAA, a notable decrease in efficiency was observed. But even so, the callus induction efficiency was much greater in $N$. damascena than in $N$. sativa. Also, the dynamics of callus growth was similarly intensive among the tested media compositions and explant types because after $4-5$ weeks of culture, all explants were covered with callus.

Somatic embryogenesis is a powerful biotechnological tool that can be exploited for various applications, including clonal propagation, plant improvement and germplasm conservation; it also offers an excellent system to study embryo and early plant development, morphogenesis, and genetic transformation (Zimmerman 1993; Hutchinson et al. 1996; Demeter et al. 2010; Gerdakaneh et al. 2011). Among the examples of genera from the family Ranunculaceae in which somatic embryogenesis has been employed, there are, for instance, Aconitum (Giri et al. 1993), Actaea (Pinker and Wernicke 2017; Pinker and Schenk 2018), Clematis (Mandegaran and Sieber 2000), Hepatica (Szewczyk-Taranek and Pawłowska 2015), Pulsatilla (Lin et al. 2011), and Ranunculus (Beruto and Debergh 1992; Xu et al. 2019). Only a few published reports concern somatic embryogenesis for $N$. sativa (Elhag et al. 2004) and N. damascena (Raman and Greyson 1974; Sethi and Rangaswamy 1976), in which the culture media were supplemented with NAA or kinetin. However, up to now, only Raman and Greyson (1974) presented successful production of mature somatic embryos in suspension cultures initiated from floral meristem-derived callus, whereas Sethi and Rangaswamy (1976) obtained embryos by culturing endosperm tissue on solid media. Here, we were able to efficiently induce indirect somatic embryogenesis on hypocotyl- and cotyledon-derived callus in all tested culture media variants. Such an indirect approach generally leads to the formation of both embryogenic and non-embryogenic calli. These two types of tissues can be easily distinguished according to their morphology and color, since they exhibit differences in their histological structures and cellular features (Shang et al. 2009; Carvalho et al. 2013), as also evidenced in histological sections examined in our study where typical developmental stages of somatic embryogenesis (i.e. globular-, heart-, torpedoshaped, and cotyledonary stage embryos) were recognized. Moreover, all the embryo stages were often detected on or within the same embryogenic callus, as similarly observed in previous studies dealing with different species of Ranunculaceae (Elhag et al. 2004; Pinker and Wernicke 2017).

We have developed an effective method for somatic embryo production to obtain more than six plants from one regenerating callus clump in less than 6 weeks. The conversion of somatic embryos into plants was performed on hormone-free media supplemented with an increased amount of glycine. Similarly, Kumar and Roy (1996) reported 
Table 2 Yield and viability of callus-derived protoplasts of Nigella damascena

\begin{tabular}{|c|c|c|c|c|c|}
\hline \multirow{2}{*}{$\begin{array}{l}\text { Explant type used } \\
\text { for callus induc- } \\
\text { tion }\end{array}$} & \multirow{2}{*}{$\begin{array}{l}\text { Callus } \\
\text { induction } \\
\text { medium }\end{array}$} & \multicolumn{2}{|c|}{$\begin{array}{l}\text { Protoplast yield } \\
\left(\times 10^{5} / \mathrm{g} \mathrm{FW}\right)\end{array}$} & \multicolumn{2}{|c|}{$\begin{array}{l}\text { Protoplast } \\
\text { viability (\%) }\end{array}$} \\
\hline & & $\mathrm{n}$ & Mean \pm SE & $\mathrm{n}$ & Mean \pm SE \\
\hline \multirow[t]{2}{*}{ Hypocotyl } & $\mathrm{KN}$ & 9 & $2.2 \pm 0.3 b$ & 9 & $54.3 \pm 5.3^{\mathrm{a}}$ \\
\hline & $\mathrm{BN}$ & 9 & $4.9 \pm 0.7 \mathrm{a}$ & 9 & $64.9 \pm 6.4^{\mathrm{a}}$ \\
\hline \multirow[t]{2}{*}{ Cotyledon } & KN & 5 & $2.9 \pm 1.1 \mathrm{ab}$ & 6 & $48.7 \pm 3.6^{a}$ \\
\hline & $\mathrm{BN}$ & 5 & $2.7 \pm 0.5 \mathrm{ab}$ & 6 & $58.3 \pm 5.4^{\mathrm{a}}$ \\
\hline Mean/Total & & 28 & $3.3 \pm 0.4$ & 30 & $57.1 \pm 2.9$ \\
\hline
\end{tabular}

$F W$ fresh weight, $n$ number of independent protoplast isolations

$\mathrm{KN}=\mathrm{MS}$ medium $+2.0 \mathrm{mg} \mathrm{L}^{-1}$ kinetin $+1.0 \mathrm{mg} \mathrm{L}^{-1} \mathrm{NAA} ; \mathrm{BN}=$ $\mathrm{MS}$ medium + 3.0 $\mathrm{mg} \mathrm{L}^{-1} \mathrm{BAP}+0.5 \mathrm{mg} \mathrm{L}^{-1} \mathrm{NAA}$

Means followed by the same letters within a column were not significantly different at $P=0.05$ the effective maturation of somatic embryos in $N$. sativa on hormone-free media. Additionally, Elhag et al. (2004) used various combinations of NAA and 2,4-D in both solid and liquid media and induced somatic embryos formation in $N$. sativa, but the conversion into plants has never been observed. Based on the obtained results in this research for $N$. damascena, it can be concluded that somatic embryogenesis is the most effective in callus derived from hypocotyls exposed to MS medium supplemented with $2 \mathrm{mg} \mathrm{L}^{-1}$ kinetin and $1 \mathrm{mg} \mathrm{L}^{-1}$ NAA. It should also be emphasized that at the same time, callus induction on this medium from hypocotyl explants was the least effective.

Plant protoplasts can be isolated from various plant organs and their tissues by enzymatic digestion of source tissue leading to cell wall removal. Theoretically, protoplasts are totipotent which means they have the ability to de-differentiate, re-construct the cell wall, re-enter the cell cycle,
Fig. 4 Plating efficiency in 10 day old callus-derived protoplast cultures of Nigella damascena using CPP1 or CPP2 protoplast media supplemented with different plant growth regulators. a Effect of phytosulfokine (PSK) on protoplasts originating from hypocotyl-derived callus; $\mathbf{b}$ effect of putrescine $(\mathrm{Pu})$ alone and in combination with PSK on protoplasts originating from either hypocotyl- or cotyledonderived callus; $50 \mathrm{Pu}, 100 \mathrm{Pu}$ $=50$ or $100 \mu \mathrm{M}$ putrescine, respectively; $P S K=100 \mathrm{nM}$ phytosulfokine

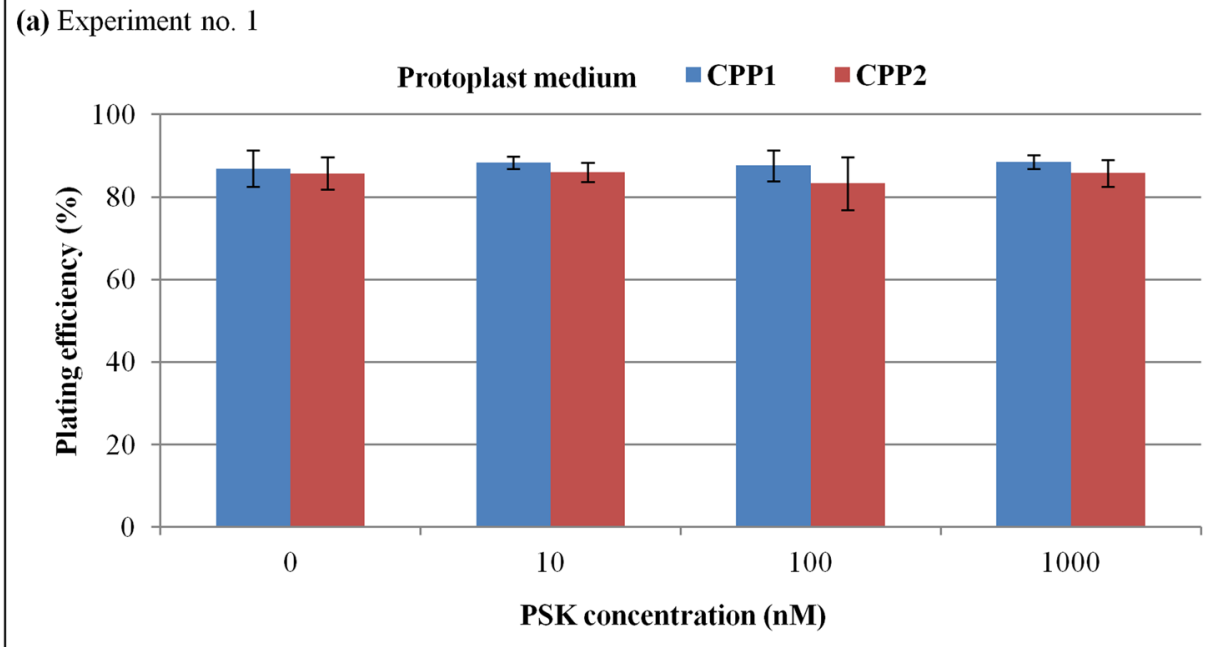

(b) Experiment no. 2

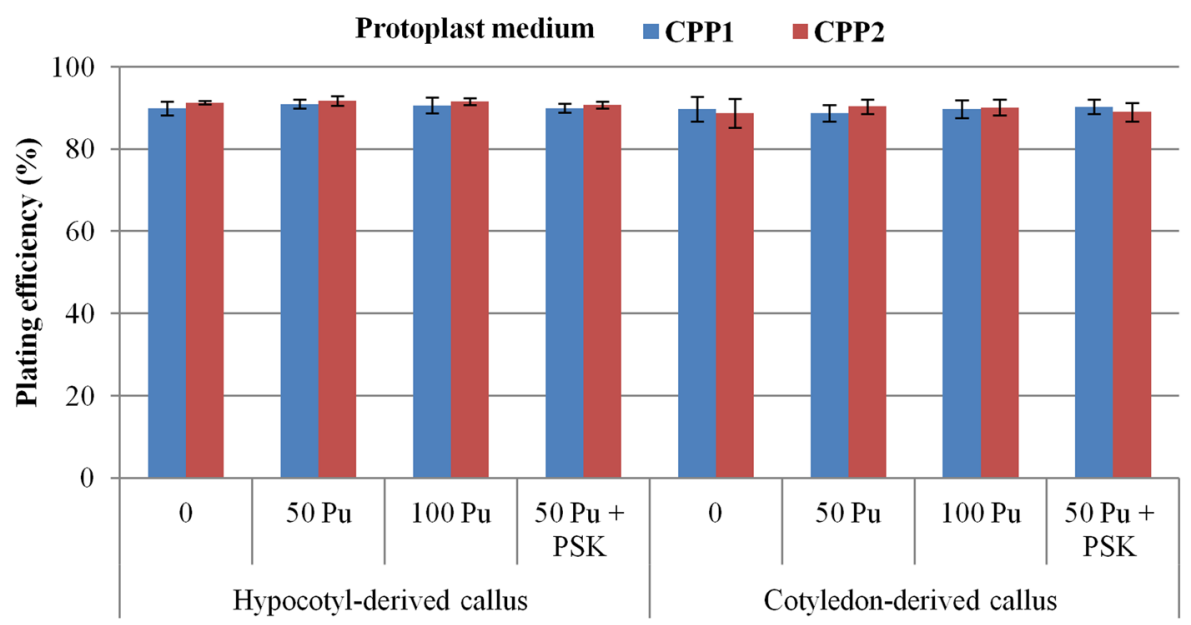

Protoplast source and protoplast media supplementation 
Table 3 Callus development in 60 day old protoplast cultures of Nigella damascena, depending on the protoplast source, basal medium (CPP1 or CPP2), and combination of phytosulfokine and putrescine

\begin{tabular}{|c|c|c|c|c|}
\hline \multirow[t]{2}{*}{$\begin{array}{l}\text { Protoplast } \\
\text { source }\end{array}$} & \multirow{2}{*}{$\begin{array}{l}\text { Phyto- } \\
\text { sulfokine } \\
\text { (PSK) } \\
(\mathrm{nM})\end{array}$} & \multirow{2}{*}{$\begin{array}{l}\text { Putrescine } \\
(\mathrm{Pu}) \\
(\mu \mathrm{M})\end{array}$} & \multicolumn{2}{|c|}{$\begin{array}{l}\text { Callus development on } \\
\text { media* }\end{array}$} \\
\hline & & & CPP1 (KN) & $\mathrm{CPP} 2(\mathrm{BN})$ \\
\hline \multirow{4}{*}{$\begin{array}{l}\text { Hypocotyl- } \\
\text { derived cal- } \\
\text { lus (exp. 1) }\end{array}$} & 0 & 0 & + & + \\
\hline & 10 & 0 & + & + \\
\hline & 100 & 0 & + & + \\
\hline & 1000 & 0 & + & + \\
\hline \multirow{4}{*}{$\begin{array}{l}\text { Hypocotyl- } \\
\text { derived cal- } \\
\text { lus (exp. 2) }\end{array}$} & 0 & 0 & + & + \\
\hline & 0 & 50 & + & + \\
\hline & 0 & 100 & + & + \\
\hline & 100 & 50 & + & + \\
\hline \multirow{4}{*}{$\begin{array}{l}\text { Cotyledon- } \\
\text { derived cal- } \\
\text { lus (exp. 2) }\end{array}$} & 0 & 0 & +++ & + \\
\hline & 0 & 50 & +++ & + \\
\hline & 0 & 100 & +++ & + \\
\hline & 100 & 50 & +++ & + \\
\hline
\end{tabular}

*Protoplasts in CPP1 medium originated from callus maintained on $\mathrm{KN}$ medium while those in CPP2 medium originated from callus maintained on BN medium. (+) poor callus growth; $(+++)$ intensive callus growth-alginate layers were overgrown with callus. exp. 1 and exp. 2-independent experiments

go through repeated mitotic divisions, and then proliferate and develop into unorganized callus tissue, individual plant organs, or complete plant organisms (Eeckhaut et al. 2013). This property makes protoplasts a convenient material in basic research focused on cell biology and mechanisms of cell differentiation, as well as in universally understood biotechnology, including somatic hybridization to generate new genetic diversity via protoplast fusion (Jiang et al. 2013). Although there are some known protocols for protoplastto-plant systems in a number of species (Davey et al. 2005; Godel-Jędrychowska et al. 2019), especially cultivated species, the efficiency to regenerate complete plant or even callus tissue is still low or occasional. In comparison to agricultural crops, there is a limited number of reports on protoplast cultures applied to medicinal plants (Pan et al. 2003; Thomas 2009; Aoyagi 2011; Eeckhaut et al. 2013) and only two of them refer to N. sativa (Jha and Roy 1979) and $N$. damascena (Binding et al. 1981).

To our best knowledge, the data presented here demonstrate, for the first time, a complete and successful protocol for plant regeneration in protoplast cultures of $N$. damascena.
The proposed system of protoplast isolation and regeneration is based on the protocol established for carrot (Grzebelus et al. 2012a; Grzebelus and Skop 2014; Maćkowska et al. 2014) and includes: (1) preplasmolysis of source tissue; (2) enzymatic digestion of source tissue in a mixture of cellulase and pectolyase; (3) embedding of purified protoplasts in a filter-sterilized alginate matrix; (4) culture of embedded protoplasts in liquid, modified CPP medium supplemented with callus-inducing growth hormones; (5) release of protoplastderived tissue from the alginate matrix; (6) multiplication of protoplast-derived tissue on callus induction media; and (7) maturation of somatic embryos and plant regeneration on a hormone-free medium.

The conditions applied to protoplast isolation from $N$. damascena callus tissue obtained acceptable protoplast yield, i.e. about $3 \times 10^{5}$ cells per $g$ of callus fresh weight, with the average cell viability reaching $60 \%$. These values have been considered sufficient for most protoplast-based applications (Davey et al. 2010; Maćkowska et al. 2014; Godel-Jędrychowska et al. 2019). Callus tissue is a much more convenient protoplast source than the more common suspension cultures, which are an excellent source of protoplasts due to their high embryogenic ability, however, the establishment and maintenance of suspension culture are laborious and time consuming (Grzebelus et al. 2012a). We have found that callus-derived protoplasts of $N$. damascena have a high potential to re-construct the cell wall and to re-enter mitotic divisions in early cultures. The plating efficiency recorded in basal protoplast culture media (CPP1 and CPP2) reached about $90 \%$, while even three times lower values are commonly considered satisfactory (Grzebelus et al. 2012b; Maćkowska et al. 2014; Kiełkowska and Adamus 2019). Due to such high mitotic activity of cells at the early-stage cultures, additional supplementation of culture media with different concentrations of PSK, Pu, or a combination of PSK and $\mathrm{Pu}$ was ineffective. The positive effect of PSK, a peptidyl plant growth factor, on cell proliferation was reported for the first time by Matsubayashi and Sakagami (1996) in mesophyll cell cultures of Asparagus officinalis. It was also shown to playing a role in diverse aspects of plant development and reproduction, including the formation of tracheary elements and adventitious roots (Yamakawa et al. 1998; Matsubayashi et al. 1999), somatic embryogenesis (Ochatt et al. 2018; Gałuszka et al. 2019), and pollen germination (Chen et al. 2000). Thus far, its ability to promote mitotic activity was confirmed in numerous suspension and protoplast cultures of both monocotyledonous and dicotyledonous species (Matsubayashi et al. 1997, 2004; Maćkowska et al. 2014; Kiełkowska and Adamus 2017, 2019) and as a cell division promoter, PSK-treatment may be particularly preferred in cell cultures of so called recalcitrant species (Grzebelus et al. 2012b). Similar to $\mathrm{PSK}$, exogenous application of $\mathrm{Pu}$, a plant growth regulator 
belonging to the polyamines, among others, may stimulate cellular divisions, as it was demonstrated in embryogenic cultures of Araucaria angustifolia (Steiner et al. 2007) and Picea abies (Vondráková et al. 2015). The results presented here strongly show that early-stage cultures of $N$. damascena protoplasts do not need chemical nursing with PSK, $\mathrm{Pu}$, or a combination of both. However, we cannot exclude the possibility that the concentrations of these compounds present in late-stage cultures were too low to be effective.

Although in late-stage cultures further growth of most cell aggregates was arrested, a sufficiently large number of them developed into the mini-callus stage and were easily proliferated on callus induction media. This specific pattern of protoplast and protoplast-derived callus development is similar to that reported for $N$. sativa protoplasts (Jha and Roy 1979). It might be speculated that the differences in cell proliferation rate in protoplast cultures originating from hypocotyl- and cotyledon-derived callus are linked to a tissue specific gene expression profile in the initial callus used for protoplast isolation following incomplete cell differentiation process during protoplasting. It seems that the transfer of protoplast-derived tissue, such as hypocotyl- and cotyledon-derived callus, to hormone-free media with light conditioning stimulates somatic embryogenesis, as well as maturation of somatic embryos and their conversion into plants. Similarly, such a convenient regeneration system from protoplast culture has been established for carrot, a model species for plant tissue culture (Grzebelus et al. 2012a; Maćkowska et al. 2014; Kiełkowska et al. 2019).

\section{Conclusions}

In this study, we established a simple and effective plant regeneration system for Nigella damascena $\mathrm{L}$. via indirect somatic embryogenesis, using cotyledons and hypocotyls as a source of explants for callus induction. Both types of explants displayed a high callus induction potential when cultured on two different MS-based media supplemented with either kinetin and NAA (KN medium) or BAP and NAA (BN medium), however, the latter appeared to be more effective. The greatest plant regeneration capacity was observed for callus developed from hypocotyl explants on $\mathrm{KN}$ medium and then cultured on hormone-free medium, which had the largest number of regenerated plants. Irrespective of callus origin, $N$. damascena callus tissue cultured for a period of over 2 years maintained its regeneration capacity at a level comparable to short-term culture. Here, we also report, for the first time, an efficient procedure for a plant regeneration system in protoplast cultures of $N$. damascena, showing the versatility of the system used in carrot and previously developed in our laboratory.
The protocol for callus induction and maintenance described in this research paves the way for future experiments aiming to study the biosynthesis of bioactive metabolites in $N$. damascena. Moreover, the presented plant regeneration system provides an important tool for genetic manipulation and further improvement of this valuable medicinal plant. In addition, the protocol for protoplast isolation and regeneration may be useful in producing somatic hybrid cell lines, with unique composition of pharmaceuticals, through protoplast fusion.

Acknowledgements The authors thank Paweł Kożuch, Urszula Ustrzycka, Kamila Siekaniec, and Anna Lupa for excellent technical assistance by callus induction as well as protoplast isolation and culture. This research was supported by the Ministry of Science and Higher Education of the Republic of Poland from subvention funds.

Author contributions Conceptualization: MK-C and EG; Methodology: MK-C, EG and DK; Investigation: MK-C, AM-P, AL and DK; Formal analysis: MK-C, EG, AM-P and DK; Visualization: MK-C, EG, AM-P and DK; Writing-Original Draft: MK-C, EG, DK, AL and RB; Writing-Review \& Editing: MK-C, EG, DK and RB; Funding acquisition: RB and EG; Project administration: MK-C and EG; Resources: RB and EG; Supervision: MK-C and EG; All authors contributed to the final manuscript. All authors read and approved the manuscript.

\section{Compliance with ethical standards}

Conflict of interest The authors declare that they have no conflict of interest.

Open Access This article is licensed under a Creative Commons Attribution 4.0 International License, which permits use, sharing, adaptation, distribution and reproduction in any medium or format, as long as you give appropriate credit to the original author(s) and the source, provide a link to the Creative Commons licence, and indicate if changes were made. The images or other third party material in this article are included in the article's Creative Commons licence, unless indicated otherwise in a credit line to the material. If material is not included in the article's Creative Commons licence and your intended use is not permitted by statutory regulation or exceeds the permitted use, you will need to obtain permission directly from the copyright holder. To view a copy of this licence, visit http://creativecommons.org/licenses/by/4.0/.

\section{References}

Anthony P, Otoni W, Power JB, Lowe TC, Davey MR (1999) Protoplast isolation culture and plant regeneration from Passiflora. In: Hall RD (ed) Methods in molecular biology—plant cell culture protocols. Humana Press, Totowa, pp. 169-181. https://doi.org/https:// doi.org/10.1385/1-59259-583-9:169

Aoyagi H (2011) Application of plant protoplasts for the production of useful metabolites. Biochem Eng J 56:1-8. https://doi. org/10.1016/j.bej.2010.05.004

Beruto M, Debergh P (1992) Somatic embryogenesis in Ranunculus asiaticus $\mathrm{L}$. hybr. thalamus cultivated in vitro. Plant Cell Tiss Organ Cult 29:161-165. https://doi.org/10.1007/BF00034348

Binding H, Nehls R, Kock R, Finger J, Mordhorst G (1981) Comparative studies on protoplast regeneration in herbaceous species of 
the Dicotyledoneae class. Z Pflanzenphysiol 101:119-130. https ://doi.org/10.1016/S0044-328X(81)80046-3

Boubertakh B, Liu XG, Cheng XL, Li P (2013) A spotlight on chemical constituents and pharmacological activities of Nigella glandulifera Freyn et Sint Seeds. J Chem 2013:820183. https://doi. org/10.1155/2013/820183

Bridgen MP, Van Houtven W, Eeckhaut T (2018) Plant tissue culture techniques for breeding. In: Van Huylenbroeck J (ed) Ornamental crops. Handbook of plant breeding, vol 11. Springer, Cham, pp. 127-144

Carvalho MAF, Paiva R, Alves E, Nogueira RC, Stein VC, Castro EM, Paiva PDO, Vargas DP (2013) Morphogenetic potential of native passion fruit (Passiflora gibertii N. E. Brown.) calli. Braz J Bot 36:141-151. https://doi.org/10.1007/s40415-013-0015-4

Charles DJ (2013) Antioxidant properties of spices, herbs and other sources. Springer, New York

Chaudhry H, Fatima N, Ahmad IZ (2014) Establishment of callus and cell suspension cultures of Nigella sativa L. for thymol production. Int J Pharm Pharm Sci 6:788-794

Chen YF, Mastubayashi Y, Sakagami Y (2000) Peptide growth factor phytosulphokine- $\alpha$ contributes to the pollen population effect. Planta 211:752-755

D'Antuono LF, Moretti A, Lovato AFS (2002) Seed yield, yield components, oil content and essential oil content and composition of Nigella sativa L. and Nigella damascena L. Ind Crop Prod 15:59-69. https://doi.org/10.1016/S0926-6690(01)00096-6

Davey MR, Anthony P, Patel D, Power JB (2010) Plant protoplasts: isolation, culture and plant regeneration. In: Davey MR, Anthony $\mathrm{P}$ (eds) Plant cell culture essential methods. Wiley-Blackwell, New York, pp. 153-173. https://doi.org/https://doi.org/10.1002/97804 70686522.ch9

Davey MR, Anthony P, Power JB, Lowe KC (2005) Plant protoplast technology: current status. Acta Physiol Plant 27:117-130. https ://doi.org/10.1007/s11738-005-0044-0

de Kraker JW, Franssen MC, de Groot A, Konig WA, Bouwmeester HJ (1998) (+)-Germacrene A biosynthesis - the committed step in the biosynthesis of bitter sesquiterpene lactones in chicory. Plant Physiol 117:1381-1392. https://doi.org/10.1104/pp.117.4.1381

Demeter Z, Surányi G, Molnár VA, Sramkó G, Beyer D, Kónya Z, Vasas G, M-Hamvas M, Máthé C (2010) Somatic embryogenesis and regeneration from shoot primordia of Crocus heuffelianus. Plant Cell Tiss Organ Cult 100:349-353. https://doi.org/10.1007/ s11240-009-9645-4

Dirks R, Sidorov V, Tulmans C (1996) A new protoplast culture system in Daucus carota L. and its applications for mutant selection and transformation. Theor Appl Genet 93:809-815. https://doi. org/10.1007/BF00224080

Ebrahimi M, Mokhtari A (2017) Engineering of secondary metabolites in tissue and cell culture of medicinal plants: an alternative to produce beneficial compounds using bioreactor technologies. In: Abdullah S, Chai-Ling H, Wagstaff C (eds) Crop improvement. Springer, Cham, pp 137-167

Edris AE (2009) Anti-cancer properties of Nigella spp. essential oils and their major constituents, thymoquinone and $\beta$-elemene. Curr Clin Pharmacol 4:43-46. https://doi.org/10.2174/1574884097 87236137

Eeckhaut T, Lakshmanan PS, Deryckere D, Van Bockstaele E, Van Huylenbroeck J (2013) Progress in plant protoplast research. Planta 238:991-1003. https://doi.org/10.1007/s00425-013-1936-7

Elhag H, El-Olemy MM, Al-Said MS (2004) Enhancement of somatic embryogenesis and production of developmentally arrested embryos in Nigella sativa L. HortScience 39:321-323. https:// doi.org/https://doi.org/10.21273/hortsci.39.2.321

Fico G, Braca A, Tome F, Morelli I (2000) Phenolic derivatives from Nigella damascena seeds. Pharm Biol 38:371-373. https://doi. org/10.1076/phbi.38.5.371.5967
Gałuszka A, Gustab M, Tuleja M (2019) In vitro morphogenetic responses from obligatory apomictic Taraxacum belorussicum Val. N. Tikhom seedlings explants. Plant Cell Tiss Organ Cult 139:505-522. https://doi.org/10.1007/s11240-019-01694-4

Gamborg OL, Miller RA, Ojima K (1968) Nutrient requirements of suspension cultures of soybean root cells. Exp Cell Res 50:151158. https://doi.org/10.1016/0014-4827(68)90403-5

Gerdakaneh M, Mozafari AA, Sioseh-mardah A, Sarabi B (2011) Effects of different amino acids on somatic embryogenesis of strawberry. Acta Physiol Plant 33:1847-1852. https://doi. org/10.1007/s11738-011-0725-9

Giri A, Ahuja PS, Kumar PVA (1993) Somatic embryogenesis and plant regeneration from callus cultures of Aconitum heterophyllum Wall. Plant Cell Tiss Organ Cult 32:213-218. https://doi. org/10.1007/BF00029845

Godel-Jędrychowska K, Maćkowska K, Kurczyńska E, Grzebelus E (2019) Composition of the reconstituted cell wall in protoplastderived cells of Daucus is affected by phytosulfokine (PSK). Int J Mol Sci 20:5490. https://doi.org/10.3390/ijms20215490

Grzebelus E, Maćkowska K, Macko-Podgórni K, Kiełkowska A, Szklarczyk M, Baranski R, Grzebelus D (2019) Application of protoplast technology to Apiaceae species. Acta Hortic 1264:67-74. https://doi.org/https://doi.org/10.17660/ActaH ortic. 2019.1264 .8

Grzebelus E, Skop L (2014) Effect of $\beta$-lactam antibiotics on plant regeneration in carrot protoplast cultures. In Vitro Cell Dev Biol-Plant 50:568-575. https://doi.org/https://doi.org/10.1007/ s11627-014-9626-0

Grzebelus E, Szklarczyk M, Barański R (2012) An improved protocol for plant regeneration from leaf- and hypocotyl-derived protoplasts of carrot. Plant Cell Tiss Organ Cult 109:101-109. https://doi.org/10.1007/s11240-011-0078-5

Grzebelus E, Szklarczyk M, Greń J, Śniegowska K, Jopek M, Kacińska I, Mrożek K (2012) Phytosulfokine stimulates cell divisions in sugar beet (Beta vulgaris L.) mesophyll protoplast cultures. Plant Growth Regul 67:93-100. https://doi. org/10.1007/s10725-011-9654-2

Hoseinpanahi S, Majdi M, Mirzaghaderi G (2016) Effects of growth regulators on in vitro callogenesis and regeneration of black cumin (Nigella sativa). Iran J Rangel Forest Plant Breed 24:232-241

Hussain S, Fareed S, Ansari S, Rahman A, Ahmad Z, Saeed M (2012) Current approaches toward production of secondary plant metabolites. J Pharm Bioallied Sci 4:10-20. https://doi. org/10.4103/0975-7406.92725

Hutchinson MJ, Murch SJ, Saxena PK (1996) Morphoregulatory role of thidiazuron: evidence of the involvement of endogenous auxin in thidiazuron-induced somatic embryogenesis of geranium (Pelargonium $\times$ hortorum Bailey). J Plant Physiol 149:573-579. https ://doi.org/10.1016/S0176-1617(96)80336-1

Jabbour F, Udron M, Le Guilloux M, Goncalves B, Manicacci D, Nadot S, Damerval C (2015) Flower development schedule and $A G A$ MOUS-like gene expression patterns in two morphs of Nigella damascena (Ranunculaceae) differing in floral architecture. Bot J Linn Soc 178:608-619. https://doi.org/10.1111/boj.12297

Jha TB, Roy SC (1979) Rhizogenesis from Nigella sativa protoplasts. Protoplasma 101:139-142. https://doi.org/10.1007/BF01293443

Jiang F, Zhu J, Liu H-L (2013) Protoplasts: a useful research system for plant cell biology, especially dedifferentiation. Protoplasma 250:1231-1238. https://doi.org/10.1007/s00709-013-0513-z

Kao KN, Michayluk MR (1975) Nutritional requirements for growth of Vicia hajastana cells and protoplasts at a very low population density in liquid media. Planta 126:105-110. https://doi.org/10.1007/ BF00380613

Kazmi A, Khan MA, Ali H, Dilshad E (2019) Biotechnological approaches for production of bioactive secondary metabolites in 
Nigella sativa: an up-to-date review. IJSM 6:172-195. https://doi. org/https://doi.org/10.21448/ijsm.575075

Khan MA, Chen HC, Tania M, Zhang DZ (2011) Anticancer activities of Nigella sativa (black cumin). Afr J Tradit Complem 8:226-232. https://doi.org/10.4314/ajtcam.v8i5S.10

Kiełkowska A, Adamus A (2017) Early studies on the effect of peptide growth factor phytosulfokine- $\alpha$ on Brassica oleracea var. capitata L. protoplasts. Acta Soc Bot Pol 86:3558. https://doi.org/10.5586/ asbp. 3558

Kiełkowska A, Adamus A (2019) Peptide growth factor phytosulfokine- $\alpha$ stimulates cell divisions and enhances regeneration from $B$. oleracea var. capitata $\mathrm{L}$. protoplast culture. J Plant Growth Regul 38:931-944. https://doi.org/10.1007/s0034 4-018-9903-y

Kiełkowska A, Grzebelus E, Lis-Krzyścin A, Maćkowska A (2019) Application of the salt stress to the protoplast cultures of the carrot (Daucus carota L.) and evaluation of the response of regenerants to soil salinity. Plant Cell Tiss Organ Cult 137:379-395. https:// doi.org/10.1007/s11240-019-01578-7

Kökdil G, Yilmaz H (2005) Analysis of the fixed oils of the genus Nigella L. (Ranunculaceae) in Turkey. Biochem Syst Ecol 33:1203-1209. https://doi.org/10.1016/j.bse.2005.07.013

Kumar S, Roy SG (1996) Rapid in vitro propagation of Nigella sativa by axillary bud multiplication and somatic embryogenesis. Cytobios 87:99-106

Liao H, Fu X, Zhao H, Cheng J, Zhang R, Yao X, Duan X, Shan H, Kong H (2020) The morphology, molecular development and ecological function of pseudonectaries on Nigella damascena (Ranunculaceae) petals. Nat Commun 11:1777. https://doi. org/10.1038/s41467-020-15658-2

Lin GZ, Zhao XM, Hong SK, Lian YJ (2011) Somatic embryogenesis and shoot organogenesis in the medicinal plant Pulsatilla koreana Nakai. Plant Cell Tiss Organ Cult 106:93-103. https:// doi.org/10.1007/s11240-010-9897-z

Maćkowska K, Jarosz A, Grzebelus E (2014) Plant regeneration from leaf-derived protoplasts within the Daucus genus: effect of different conditions in alginate embedding and phytosulfokine application. Plant Cell Tiss Organ Cult 117:241-252. https:// doi.org/10.1007/s11240-014-0436-1

Mandegaran Z, Sieber VK (2000) Somatic embryogenesis in Clematis integrifolia $\times C$. viticella. Plant Cell Tiss Organ Cult 62:163-165. https://doi.org/10.1023/A:1026514707169

Matsubayashi Y, Goto T, Sakagami Y (2004) Chemical nursing: phytosulfokine improves genetic transformation efficiency by promoting the proliferation of surviving cells on selective media. Plant Cell Rep 23:155-158. https://doi.org/10.1007/ s00299-004-0816-9

Matsubayashi Y, Sakagami Y (1996) Phytosulfokine, sulfated peptides that induce the proliferation of single mesophyll cells of Asparagus officinalis L. Proc Natl Acad Sci USA 93:76237627. https://doi.org/10.1073/pnas.93.15.7623

Matsubayashi Y, Takagi L, Omura N, Morita A, Sakagami Y (1999) The endogenous sulfated pentapeptide phytosulfokine-a stimulates tracheary element differentiation of isolated mesophyll cells of Zinnia. Plant Physiol 120:1043-1048

Matsubayashi Y, Takagi L, Sakagami Y (1997) Phytosulfokine-a, a sulfated pentapeptide, stimulates the proliferation of rice cells by means of specific high-and low-affinity binding sites. Proc Natl Acad Sci USA 94:13357-13362. https://doi.org/10.1073/ pnas.94.24.13357

Mulabagal V, Chen-Yue L, Shu-Fung L, Satish MN, Chien YL, HsinSheng T (2004) Studies on the production of some important secondary metabolites from medicinal plants by plant tissue cultures. Bot Bull Acad Sin 45:1-22
Mulabagal V, Hsin-Sheng T (2004) Plant cell cultures-an alternative and efficient source for the production of biologically important secondary metabolites. Int J Appl Sci Eng 2:29-48

Murashige T, Skoog F (1962) A revised medium for rapid growth and bio assays with tobacco tissue cultures. Physiol Plantarum 15:473-497. https://doi.org/10.1111/j.1399-3054.1962.tb080 52. $\mathrm{x}$

Noor NA, Fahmy HM, Mohammed FF, Radwan NM, Elsayed AA (2015) Nigella sativa amliorates inflammation and demyelination in the experimental autoimmune encephalomyelitis-induced Wistar rats. Int J Clin Exp Patho 8:6269-6286

Ochatt S, Conreux C, Mcolo RM, Despierre G, Magnin-Robert J-B, Raffiot B (2018) Phytosulfokine-alpha, an enhancer of in vitro regeneration competence in recalcitrant legumes. Plant Cell Tiss Organ Cult 135:189-201. https://doi.org/10.1007/s1124 0-018-1455-0

Pan ZG, Liu CZ, Murch SJ, El-Demerdash M, Praveen K, Saxena PK (2003) Plant regeneration from mesophyll protoplasts of the Egyptian medicinal plants Artemisia judaica L. and Echinops spinosissimus Turra. Plant Sci 165:681-687. https://doi. org/10.1016/S0168-9452(03)00220-6

Pinker I, Schenk R (2018) Black cohosh (Actaea racemosa L.). In: Jain SM, Gupta P (eds) Step wise protocols for somatic embryogenesis of important woody plants, 2nd edn. Springer, Cham, pp 83-93. https://doi.org/https://doi.org/10.1007/978-3-319-79087 $-9 \_6$

Pinker I, Wernicke M (2017) Development, maturation and conversion of somatic embryos of Actaea racemosa L. Acta Hortic 1155:135-140. https://doi.org/https://doi.org/10.17660/ActaH ortic.2017.1155.18

Raman K, Greyson RI (1974) In vitro induction of embryoids in tissue cultures of Nigella damascena. Can J Bot 52:1988-1989. https://doi.org/10.1139/b74-253

Sethi M, Rangaswamy NS (1976) Endosperm embryoids in cultures of Nigella damascena. Curr Sci 45:109-111

Shahzad R, Khan AL, Bilal S, Waqas M, Kang SM, Lee IJ (2017) Inoculation of abscisic acid-producing endophytic bacteria enhances salinity stress tolerance in Oryza sativa. Environ Exp Bot 136:68-77. https://doi.org/10.1016/j.envex pbot.2017.01.010

Shang HH, Liu CL, Zhang CJ, Li FL, Hong WD, Li FG (2009) Histological and ultrastructural observation reveals significant cellular differences between Agrobacterium transformed embryogenic and non-embryogenic calli of cotton. J Integr Plant Biol 51:456-465. https://doi.org/10.1111/j.1744-7909.2009.00824.x

StatSoft, Inc. (2014) STATISTICA (data analysis software system), version 12. www.statsoft.com

Steiner N, Santa-Catarina C, Silveira V, Floh EIS, Guerra MP (2007) Polyamine effects on growth and endogenous hormones levels in Araucaria angustifolia embryogenic cultures. Plant Cell Tiss Organ Cult 89:55-62. https://doi.org/10.1007/s1124 0-007-9216-5

Szewczyk-Taranek B, Pawłowska B (2015) Recurrent somatic embryogenesis and plant regeneration from seedlings of Hepatica nobilis Schreb. Plant Cell Tiss Organ Cult 120:1203-1207. https://doi.org/10.1007/s11240-014-0661-7

Telci SI, Sahin-Yaglioglu A, Eser F, Aksit H, Demirtas I, Tekin S (2014) Comparison of seed oil composition of Nigella sativa L. and $N$. damascena $\mathrm{L}$. during seed maturation stages. J Am Oil Chem Soc 91:1723-1729. https://doi.org/10.1007/s1174 6-014-2513-3

Thomas TD (2009) Isolation, callus formation and plantlet regeneration from mesophyll protoplasts of Tylophora indica (Burm. f.) Merrill: an important medicinal plant. Vitro Cell Dev Biol-Plant 45:591-598. https://doi.org/10.1007/s11627-008-9190-6 
Vondráková Z, Eliášová K, Vágner M, Martincová O, Cvikrová M (2015) Exogenous putrescine affects endogenous polyamine levels and the development of Picea abies somatic embryos. Plant Growth Regul 75:405-414. https://doi.org/10.1007/s1072 5-014-0001-2

Wajs A, Bonikowski R, Kalemba D (2009) Different isolation methods for determination of composition of volatiles from Nigella damascena L. seeds. Nat Prod Commun 4:1577-1580. https:// doi.org/10.1177/1934578X0900401125

Xu KD, Wang W, Yu DS, Li XL, Chen JM, Feng BJ, Zhao YW, Cheng MJ, Liu XX, Li CW (2019) NAA at a high concentration promotes efficient plant regeneration via direct somatic embryogenesis and SE-mediated transformation system in Ranunculus sceleratus. Sci Rep 9:18321. https://doi.org/10.1038/s4159 8-019-54538-8

Yamakawa S, Sakurai C, Matsubayashi Y, Sakagami Y, Kamada H, Satoh S (1998) The promotive effects of a peptidyl plant growth factor, phytosulfokine, on the formation of adventitious roots and expression of a gene for a root-specific cystatin in cucumber hypocotyls. J Plant Res 111:453-458

Zhao L, Liu P, Che XF, Wang W, Ren Y (2011) Floral organogenesis of Helleborus thibetanus and Nigella damascena (Ranunculaceae) ant its systematic significance. Bot J Linn Soc 166:431443. https://doi.org/10.1111/j.1095-8339.2011.01142.x

Zimmerman JL (1993) Somatic embryogenesis: a model for early development in higher plants. Plant Cell 5:1411-1423. https:// doi.org/10.1105/tpc.5.10.1411

Zohary M (1983) The genus Nigella (Ranunculaceae) - a taxonomic revision. Plant Syst Evol 142:71-107

Publisher's Note Springer Nature remains neutral with regard to jurisdictional claims in published maps and institutional affiliations. 